\title{
ENERCA - European Network for Rae and Congenital Anaemias 2002-2012. 10 years of life
}

\section{Joan Lluis Vives-Corrons}

Head of ENERCA project, Head of the Red Cell Pathology Unit, Hospital Clínic, IDIBAPS of Barcelona

\section{Oral presentation}

Oral presentation is available online

Correspondence: Joan Lluis Vives-Corrons

E-mail: jl.vives@enerca.org

(C) Copyright J.L. Vives-Corrons, 2013

Licensee PAGEPress, Italy

Thalassemia Reports 2013; 3(s1):e44

doi:10.4081/thal.2013.s1.e44

This article is distributed under the terms of the Creative Commons Attribution Noncommercial License (by-nc 3.0) which permits any noncommercial use, distribution, and reproduction in any medium, provided the original author(s) and source are credited.

Parts of this work were presented at the

"3rd Pan-European Conference on Haemoglobinopathies and Rare Anaemias", Limassol (Cyprus), 24-26 October 2012. 